University of Nebraska - Lincoln

DigitalCommons@University of Nebraska - Lincoln

2020

\title{
Population and Harvest Dynamics of Midcontinent Sandhill
}

Cranes

Aaron T. Pearse

Glen A. Sargeant

Gary L. Krapu

David A. Brandt

Follow this and additional works at: https://digitalcommons.unl.edu/usgsnpwrc

Part of the Animal Sciences Commons, Behavior and Ethology Commons, Biodiversity Commons, Environmental Policy Commons, Recreation, Parks and Tourism Administration Commons, and the Terrestrial and Aquatic Ecology Commons

This Article is brought to you for free and open access by the US Geological Survey at DigitalCommons@University of Nebraska - Lincoln. It has been accepted for inclusion in USGS Northern Prairie Wildlife Research Center by an authorized administrator of DigitalCommons@University of Nebraska - Lincoln. 


\title{
Population and Harvest Dynamics of Midcontinent Sandhill Cranes
}

\author{
AARON T. PEARSE D, ${ }^{1}$ U.S. Geological Survey, Northern Prairie Wildlife Research Center, Jamestown, ND 58401, USA \\ GLEN A. SARGEANT, U.S. Geological Survey, Northern Prairie Wildlife Research Center, Jamestown, ND 58401, USA \\ GARY L. KRAPU, U.S. Geological Survey, Northern Prairie Wildlife Research Center, Jamestown, ND 58401, USA \\ DAVID A. BRANDT, U.S. Geological Survey, Northern Prairie Wildlife Research Center, Jamestown, ND 58401, USA
}

\begin{abstract}
Sandhill cranes (Antigone canadensis) inhabiting the midcontinent of North America have been hunted since the 1960s under management goals of maintaining abundance, retaining geographic distribution, and maximizing sustainable harvest. Some biologists have raised concerns regarding harvest sustainability because sandhill cranes have lower reproductive rates than other game birds. We summarized demographic information in an age-structured matrix model to better understand population dynamics and harvest. Population indices and recovered harvest since the early 1980s suggest midcontinent sandhill cranes have experienced an average long-term annual growth of $0.9 \%$; meanwhile, harvest has increased $1.8 \%$ annually. Adult survival and recruitment rates estimated from field data required modest adjustments (1-3\%) so that model-derived growth rates matched growth estimated from a long-term survey $(0.887$ adult survival and 0.199 females/breeding female). Considering $0.9 \%$ long-term annual growth, sandhill cranes could be harvested at a rate of $6.6 \%$ if harvest was additive to natural mortality (assumed to be 0.05 ) or $11.3 \%$ if harvest mortality compensated for natural mortality. Life-history characteristics for long-lived organisms and demographic evidence suggested that hunter harvest was primarily additive. Differential harvest rates of segments of sandhill cranes in the midcontinent population derived from differential exposure to hunting suggested potentially unsustainable harvest for greater sandhill cranes (A. c. tabida) from 2 breeding segments. Overall, demographic evidence suggests that the harvest of sandhill cranes in the midcontinent population has been managed sustainably. Monitoring activities that reduce nuisance variation and estimate vital and harvest rates by subspecies would support continued management of sandhill cranes that are of interest to hunters and bird watchers. Published 2020. This article is a U.S. Government work and is in the public domain in the USA.
\end{abstract}

KEY WORDS age-structured population model, Antigone canadensis, hunting, sandhill crane, sustainable harvest.

Wildlife managers often set harvest regulations for populations and species when data are limited and difficult to obtain. Efforts to gather potentially disparate data and combine data into population models can provide useful information and insights. Sandhill cranes (Antigone canadensis) in the midcontinent are the only group of cranes (Gruidae) in the world hunted extensively. They also are the most abundant group of cranes worldwide, comprising 2 genetically distinct subspecies (i.e., lesser sandhill crane [A. c. canadensis] and greater sandhill cranes [A. c. tabida]) and 4 breeding segments that have partially distinct breeding grounds, migration chronology, and wintering areas (Rhymer et al. 2001, Jones et al. 2005, Harris and Mirande 2013). Sandhill cranes in the midcontinent were first legally hunted in the United States during 1961 and in Canada during 1964 (Buller 1979). As of 2019, sandhill cranes in the midcontinent were hunted in 12 states in the United States, 2 provinces in

Received: 26 September 2019; Accepted: 12 February 2020

${ }^{1}$ E-mail: apearse@usgs.gov
Canada, and several states in Mexico. Sandhill cranes are longer-lived but less fecund than other migratory game birds (Drewien et al. 1995). Low recruitment limits potential rates of population increase; thus, populations cannot recover quickly when depressed. This relatively reduced ability to recover from overharvest motivated managers to implement restrictive regulations when hunting began (Sharp and Vogel 1992). In addition to sport hunting, sandhill cranes garner considerable interest from the wildlife watching community (Lingle 1992) and a modest level of subsistence harvest, primarily in Alaska, USA (Dubovsky 2017).

Management goals for sandhill cranes in the midcontinent population include maintaining abundance and distribution across the group's geographic range and maximizing sustainable harvest (Central Flyway Webless Migratory Game Bird Technical Committee 2018). Simultaneous increases in hunter numbers and annual harvest in the past 3 decades have motivated interest in the sustainability of recent harvest (Dubovsky 2017). Analyses of spatially explicit harvest estimates and movements of sandhill cranes from different breeding segments during fall migration and winter 
suggest that exposure to hunting may be disproportionate to segment-specific abundance (Krapu et al. 2011). If differences in hunting exposure lead to disproportionate harvest rates, some segments may experience unsustainable harvest, causing population segment abundance to decline. Long-standing concern for this potential has motivated more-restricted harvest of greater sandhill cranes (Buller 1967), although no evaluation has been conducted to determine if efforts have prevented disproportionate harvest.

Insight into effects of hunting on the status of sandhill cranes has been constrained by limited information on vital rates needed for modeling population dynamics. Mathematical models developed using combinations of recruitment and survival functions have focused primarily on estimating abundances and age structures existing during the 1970s (Johnson 1979). Those efforts occurred at an early stage of sandhill crane management when hunting activity and harvest were lower than at present. Prerequisites to evaluating effects of harvest can include estimating demographic parameters and incorporating them into a population dynamics model. Reliable estimates of survival have been difficult to obtain because a limited amount of banding has taken place (Arnold et al. 2016). Previous information on annual recruitment rates come primarily from ground surveys conducted on fall staging areas in Saskatchewan, Canada, during the 1960s and 1970s (Miller and Hatfield 1974, Buller 1979). It is unclear whether recruitment rates have changed over the past several decades during a period of a marked increase in harvest and changing climate and land use.

Our overall goal was to provide insight for current and future management of sustainable harvest for all segments of sandhill cranes in the midcontinent population, which has been identified as a research need (Central Flyway Webless Migratory Game Bird Technical Committee 2018). Specific objectives included compiling or estimating vital rates, abundance, harvest, and numbers of hunters of sandhill cranes in the midcontinent population; comparing estimates of annual recruitment derived from fall age ratio surveys with those derived from more expensive and invasive methods using individually marked birds; developing a population dynamics model; and evaluating effects of harvest rates on population dynamics, including consequences of differing harvest among segments.

\section{STUDY AREA}

Sandhill cranes occur across most of North America and have been organized into various management populations (Dubovsky 2017). Sandhill cranes in the midcontinent population are the most abundant management population of cranes in the world (Gerber et al. 2014) and have a broad breeding range that extends from northwestern Minnesota, USA, to islands in the High Arctic of Canada and from western Quebec, Canada, across a large section of northeastern Russia (Krapu et al. 2011). This vast area is comprised of tundra, parkland, temperate grasslands, mixed deciduous and coniferous forest, and boreal forest. Krapu et al. (2011) designated 4 breeding segments of sandhill cranes based on spatial distributions during the breeding season (May-Aug), including Western Alaska-Siberia (WA-S), Northern Canada-Nunavut (NC-N), Westcentral Canada-Interior Alaska (WC-A), and East-central Canada-Minnesota (EC-M). Western Alaska-Siberia and $\mathrm{NC}-\mathrm{N}$ groups are composed primarily of the lesser sandhill crane (A. c. canadensis) subspecies that breed in the arctic, whereas $\mathrm{WC}-\mathrm{A}$ and $\mathrm{EC}-\mathrm{M}$ groups are composed primarily of greater sandhill cranes (A. c. tabida), birds that breed in northern parts of temperate and subarctic regions. Krapu et al. (2011) estimated that the midcontinent population comprises 63\% lesser and 37\% greater sandhill cranes. Estimated composition of segments included $42 \%$ WA-S (lesser sandhill cranes), 21\% NC-N (lesser sandhill cranes), $23 \% \mathrm{WC}-\mathrm{A}$, (greater sandhill cranes), and 14\% EC-M (greater sandhill cranes).

Primary fall-staging areas used by segments of the midcontinent population included western Saskatchewan (WA-S), central Saskatchewan (WC-A), eastern Saskatchewan (NC-N), central North Dakota (NC-N), eastern North Dakota (EC-M), southwestern Manitoba (EC-M), and Minnesota (EC-M). These areas are comprised primarily of temperate grassland or mixed forest. A primary spring-staging area is in south-central Nebraska, USA, along the Platte River, which has been detailed by Krapu et al. (2014). Finally, the wintering range of sandhill cranes of the midcontinent population also is extensive, covering areas primarily in the southern Great Plains, southwestern United States, and northern Mexico (Krapu et al. 2011).

\section{METHODS}

The United States Fish and Wildlife Service (USFWS) conducts annual monitoring of this population with an aerial survey conducted while the birds are staging at the Platte River in Nebraska (Dubovsky 2017). The survey is a transect-based sample survey of areas used by sandhill cranes in the region and includes photo-adjusted estimates to account for counting bias. Estimates from this survey provide an index of population abundance (Central Flyway Webless Migratory Game Bird Technical Committee 2018).

\section{Field Methods}

We trapped sandhill cranes and attached very high frequency (VHF) transmitters at the central Platte River Valley between Chapman and Kearney, Nebraska, during late February to early April 1998-2006. Trapping sites generally were in pastures and hay lands. We captured birds using taxidermy-mounted decoys and rocket-propelled nets (Wheeler and Lewis 1972). We selected adults based on plumage characteristics (Lewis 1979) for transmitter attachment, marking $\leq 2$ birds from each capture event based on social status (e.g., family groups or pairs) or location under the net (e.g., birds at opposite ends) to limit the chance of sampling related or paired birds. We took blood from each marked bird from the metatarsal vein below the tibiotarsus joint and placed it into a storage buffer (0.1 M Tris, $0.1 \mathrm{M}$ EDTA, 5\% SDS, $0.01 \mathrm{M} \mathrm{NaCl}$; Longmire et al. 1991) for later DNA extraction to determine mtDNA subspecies (i.e., lesser or greater sandhill 
crane; Jones et al. 2005). We attached a VHF transmitter (30-32 g, Advanced Telemetry Systems, Isanti, MN, USA) to the left leg of selected birds above the tibiotarsus with the antenna pointing down using a 2-piece leg band (Haggie Engraving, Crumpton, MD, USA). We released most captured birds simultaneously, within 30 minutes (range $=15-60 \mathrm{~min}$ ), to minimize effects of capture on social bonds. Capture and marking procedures conformed to recommendations of the American Ornithologists' Union (Fair et al. 2010) and followed the protocol contained in Study Plan 169.02, which was approved on 13 July 1998 by the Chairman of the Animal Care and Use Committee at Northern Prairie Wildlife Research Center.

To estimate recruitment (female young/adult female), we attempted to locate birds via aerial telemetry at fall staging areas in North Dakota, USA, southwestern Manitoba, Canada, and Saskatchewan every 5 days beginning in early September until mid-October, 2003-2006 (Krapu et al. 2011). When we detected a marked bird, we relayed its position to technicians distributed across fall staging areas. Using vehicle-mounted telemetry equipment, technicians attempted to locate each radio-marked bird and obtain a visual observation to determine social status (i.e., single or paired) and number of young accompanying adults. If breeding sandhill cranes successfully reared young, we expected young to remain with adults during fall staging because sandhill cranes exhibit extended parental care of young of up to 1 year (Gerber et al. 2014).

To estimate age ratios of fall-staging sandhill cranes as an independent estimate of recruitment, we conducted surveys during September-October 2003-2006. Technicians stationed in 1 of 7 geographic areas conducted 4 surveys/week. Locations corresponded with primary fall-staging locations of the 4 segments of the midcontinent population identified by Krapu et al. (2011) and included western Saskatchewan (WA-S), central Saskatchewan (WC-A), eastern Saskatchewan (NC-N), central North Dakota (NC-N), eastern North Dakota (EC-M), southwestern Manitoba (EC-M), and Minnesota (EC-M). We identified concentrated activity centers, which generally were known roosting areas, as starting points for the surveys. Technicians drove a randomly assigned direction and recorded numbers of young and adult birds observed within $400 \mathrm{~m}$ of the survey route for $16 \mathrm{~km}$.

\section{Analytical Methods}

Trend.-We estimated a long-term population trend from results of annual surveys conducted by the USFWS at the Platte River in southcentral Nebraska, 1982-2017 (Dubovsky 2017). We regressed the natural logarithm of population indices on year and exponentiated the slope to estimate of the finite population multiplier $(\lambda$; Eberhardt 2002). We also described long-term trends in estimated sandhill crane harvest and hunter numbers in the midcontinent. We obtained estimated harvest and hunter information for the United States from published estimates provided by the USFWS (Dubovsky 2017). We included retrieved harvest estimates from Dubovsky (2017:table 5). For states in the central flyway and Minnesota, we obtained estimated numbers of active sandhill crane hunters from Dubovsky (2017:table 3). For Canada, we obtained estimates of sandhill crane harvests and hunter numbers from National Harvest Survey data for the provinces of Saskatchewan and Manitoba (Canadian Wildlife Service 2017). We summed hunter numbers between countries as an estimate of annual hunter participation or effort. As with abundance indices, we estimated a long-term annual growth rate of harvest by regressing the natural $\log$ of harvest.

Recruitment and age ratios.-We used location of fall staging and subspecies determination at capture to assign each marked bird to a breeding segment. For each segment and year, we estimated recruitment from the number of female young (assumed 50:50 sex ratio) associated with radio-marked adults observed at fall-staging sites. We calculated segment- and year-specific recruitment estimates (female young/breeding female). We adjusted this initial estimate to account for individuals that had not yet entered breeding ages but could not be differentiated from breeding adults. Based on age distributions from model results, we assumed that $25 \%$ of marked birds may not have been active breeding individuals (i.e., $<3 \mathrm{yr}$ old); therefore, we discounted the denominator of the initial age ratio accordingly. We calculated yearly age ratios to represent all sandhill cranes in the population using averages weighted by the proportion each segment was estimated to be included in the population. Overall estimates were averages of yearly estimates.

We also estimated age ratios from ground surveys conducted across fall-staging areas of sandhill cranes in the midcontinent. Initially, we tallied juvenile and adult birds observed across all surveys and locations by population segment and year. Like recruitment estimates derived from radio-marked birds, we reduced the number of adults observed to account only for the estimated $75 \%$ that were of breeding age. We calculated annual recruitment estimates (juveniles/breeding adult) for each subspecies and overall by calculating averages weighted to correspond to estimated composition by each segment. We calculated estimates across years by averaging annual estimates. We calculated 95\% confidence intervals using annual mean estimates and standard errors of annual variation.

Population dynamics model.-We used a birth-pulse and post-breeding age-based matrix model to investigate annual population dynamics of female sandhill cranes (Caswell 2001). We included 4 age classes, where juveniles were $<1$ year old, yearlings were 1 year old, subadults were 2 years old, and adults were $\geq 3$ years old. Because age-specific survival rates were not available, we used a common survival rate (0.877; Arnold et al. 2016) for ages $\geq 1$. We set survival of juvenile sandhill cranes at $90 \%$ of survival for other age classes because we expected that younger birds would have increased mortality rates, but little information existed for this age class. We restricted breeding to adults because first reproduction in sandhill cranes occurs at approximately 3 years of age (Nesbitt 1992). We parameterized initial models using recruitment 


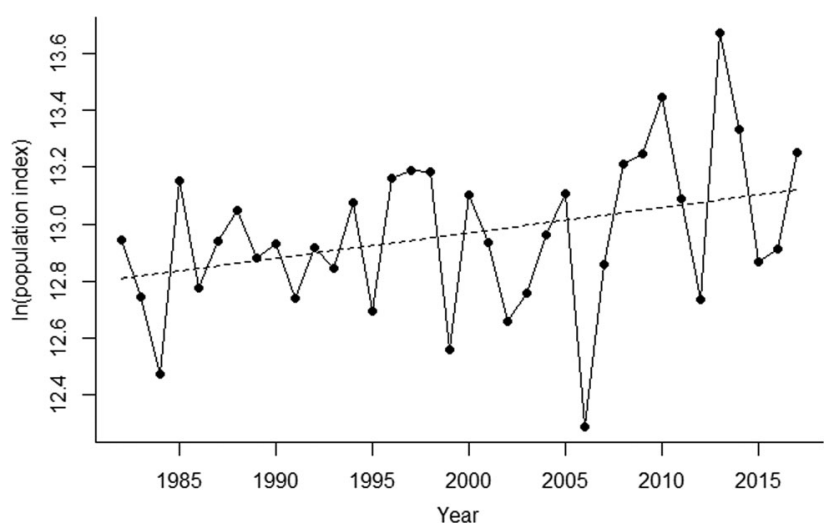

Figure 1. Natural logarithm of annual indices of sandhill crane abundance in the midcontinent population, 1982-2017. We derived estimates from a photo-adjusted aerial survey conducted each spring along the Platte River in south-central Nebraska, USA, by the United States Fish and Wildlife Service. The dashed line represents the estimated linear relationship.

estimates derived from observations of radio-marked individuals as described above. After we fully parametrized the population matrix model with survival and recruitment estimates, we used dominant eigenvalues to estimate asymptotic population growth rates and associated right eigenvectors to estimate stable age distributions. We used left eigenvectors to estimate reproductive values. We calculated elasticities as described in Caswell (2001) and interpreted them as proportional changes in $\lambda$ resulting from small proportional changes in elements of matrix models.

We used robust population management methodology described by Deines et al. (2007) and Post van der Burg and Tyre (2011) to combine independent information on population growth and evaluate empirical vital rates. We derived combinations of survival and recruitment estimates that would result in a population growth rate that matched the long-term average derived from the time series (Fig. 1). We compared these values with the combination of initial empirically estimated parameters of adult survival from Arnold et al. (2016) and recruitment from this study. Survival of other age classes were fixed based on adult survival rates. By graphing values of adult survival and recruitment that resulted in long-term growth derived from independent population surveys, we determined where empirical estimates fell and used methods described by Post van der Burg and Tyre (2011) to resolve inconsistencies by using the shortest vector between empirical estimates to those that corresponded with an established population growth rate.

We incorporated harvest rate into survival estimates using equations described by Williams et al. (2002). We used a nonharvest survival rate of 0.95 for adults because this rate has been estimated for sandhill cranes that were subject to limited harvest (Drewien et al. 1995, Fronczak et al. 2015). We initially fixed nonharvest survival and recruitment rates, allowing for calculation of expected long-term $\lambda$ at increasing harvest rates and under assumptions of additive or compensatory harvest mortality (Anderson and Burnham 1976).
In addition, we explored how variation in nonharvest survival and recruitment rates would influence sustainable harvest rate under the assumption of additive mortality by determining combinations of each vital rate that resulted in $\lambda=1.0$ while holding other model parameters constant.

To explore how differential harvest rates could affect composition of sandhill cranes in the midcontinent, we derived group-specific harvest rates for each of the 4 segments (i.e., WA-S, NC-N, WC-A, and EC-M) and by subspecies (i.e., lesser and greater sandhill cranes). We used segmentspecific estimates of hunting exposure divided by estimated segment composition from Krapu et al. (2011) and multiplied this value by an assumed overall harvest rate to calculate group-specific harvest rates. Using the same recruitment estimate and nonharvest mortality rates, we used these differential harvest rates to estimate potential group-specific population growth rates using the same matrix model structure described above. These growth rates allowed exploration of potential effects of persistent, differential growth on composition of midcontinent sandhill cranes. We used program $R$ version 3.6.0 ( $R$ Core Team 2019) for statistical analyses. Recruitment data used in analyses is available from ScienceBase (Pearse et al. 2020).

\section{RESULTS}

During 1982-2017, indices of annual abundance for sandhill cranes in the midcontinent population ranged from 216,810 in 2006 to 867,061 in 2013 (Dubovsky 2017; Fig. 1). Sandhill crane abundance increased modestly during this period $(\hat{\lambda}=1.009,95 \% \mathrm{CI}=1.001-1.017)$. Sandhill cranes recovered by hunters increased during the same period by $1.8 \%$ annually ( $95 \% \mathrm{CI}=1.3-2.3 \%$; Fig. $2 \mathrm{~A})$, from approximately 16,000 per year in the early 1980 s to approximately 30,000 per year during the mid- to late 2000 s. Hunter participation increased from approximately 9,200 hunters annually in the early 1980s to a peak of nearly 16,000 during 2007 but declined to approximately 11,000 by the mid-2010s. Variation in hunter numbers explained $56 \%$ of variation in harvest between 1980 and 2016 (Fig. 2B).

We located and observed 318 marked sandhill cranes during fall staging, 2003-2006. Most birds did not have young during fall (76\%), overall age ratio was $0.145 \pm 0.031$ (SD) female young/female, and recruitment was $0.193 \pm 0.041$ females produced per breeding female. Annual recruitment estimates were $0.146 \pm 0.135$ in 2003, $0.202 \pm 0.074$ in 2004, $0.181 \pm 0.060$ in 2005, and $0.245 \pm 0.067$ in 2006 .

During ground surveys to estimate age ratio of sandhill cranes across 7 locations and 4 years, we classified an average of 70,314 birds each year $(29,762-98,604)$. The average age ratio (female juveniles/breeding female) from surveys at fall-staging areas was $0.199(95 \% \mathrm{CI}=0.156-$ 0.242). The age ratio point estimate for lesser sandhill cranes $(0.222,95 \% \mathrm{CI}=0.182-0.262)$ exceeded the age ratio for greater sandhill cranes $(0.161,95 \% \mathrm{CI}=0.108$ 0.214), although confidence intervals overlapped; likewise, 

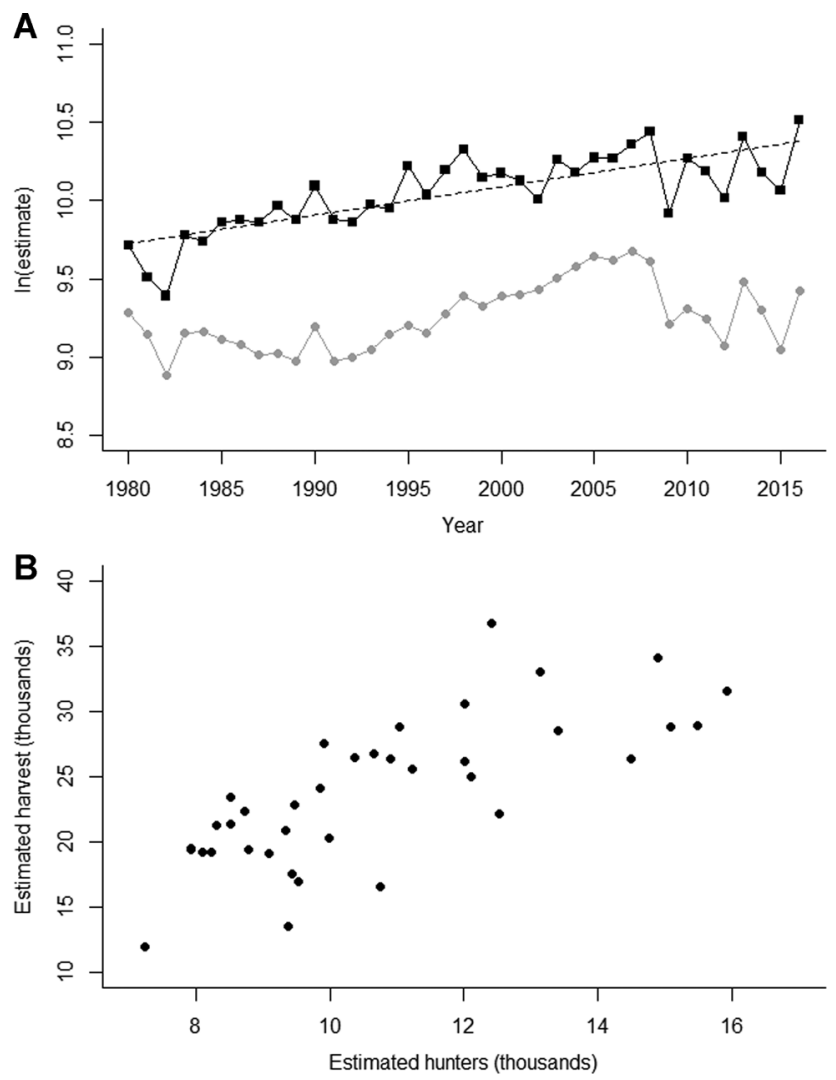

Figure 2. Natural logarithm of annual estimates of retrieved harvest of sandhill cranes (black squares) and hunters (gray circles) in the midcontinent United States and Canada, 1979-2016 (A). The dashed line represents the predicted linear relationship of harvest estimates by year. Relationship between yearly estimates of harvested sandhill cranes and hunters (B).

recruitment was $0.197(95 \% \mathrm{CI}=0.131-0.263)$ for telemetered lesser sandhill cranes and $0.188(95 \% \mathrm{CI}=0.167$ 0.209) for telemetered greater sandhill cranes.

\section{Population Dynamics Modeling}

For yearling, subadult, and adult survival values of 0.877 (Arnold et al. 2016), a juvenile survival rate of 0.789 (90\% of adult survival), and recruitment estimates from above, our population matrix model projected long-term population growth of $\hat{\lambda}=0.996$ and a stable age distribution comprising $13 \%$ juveniles, $10 \%$ yearlings, $9 \%$ subadults, and $68 \%$ adults. Rectifying the discrepancy between projected annual population growth rate and the growth rate estimated from annual surveys required only small adjustments in survival and recruitment (i.e., $1 \%$ increase in survival to $0.887 ; 3 \%$ increase in recruitment to 0.199; Fig. 3). Although this discrepancy was modest on an annual basis, adjustments were necessary because effects on projected population size compounded annually, leading to a substantial discrepancy after 35 years (i.e., $-13 \%$ projected growth; $37 \%$ growth based on surveys). The stable age distribution resulting from these vital rates comprised $13 \%$ juveniles, $11 \%$ yearlings, $9 \%$ subadults, and $67 \%$ adults. Reproductive values of age classes were 1.0 for juveniles, 1.3 for yearlings, 1.4 for subadults, and 1.6 for adults, reflecting risks of death prior to reproductive maturity. Elasticities for all transition

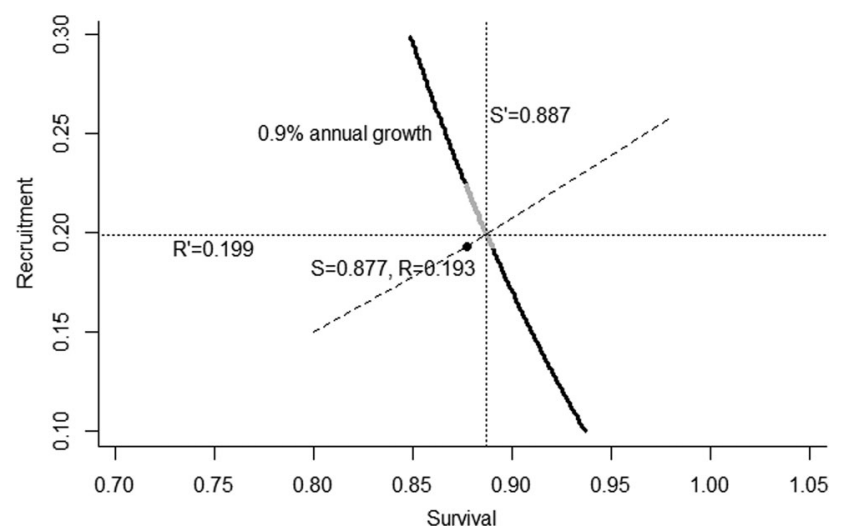

Figure 3. Recruitment (R) and survival (S) estimate combinations that resulted in a $0.9 \%$ annual growth rate (solid black line) based on a population dynamics model of sandhill cranes in the midcontinent population. We adjusted the initial empirical estimates (black circle) by finding the combination of vital rates closest to empirical estimates (dashed black line). The gray solid line represents potential combinations bounded by adjusting only 1 rate at a time.

probabilities were 0.089 except for adult survival, which had an elasticity of 0.646 .

We adjusted vital rates and projected population growth to assess effects of harvest rates on population dynamics. Increasing adult survival to 0.95 , the rate reported for nonhunted populations (Drewien et al. 1995, Fronczak et al. 2015), increased annual growth to $7.4 \%$, which also represented the sustainable harvest rate if hunting mortality was additive. An additive harvest rate of $6.6 \%$ matched the long-term annual growth rate of $0.9 \%$ observed for the midcontinent population, which was estimated from annual surveys. If harvest mortality compensated for natural mortality, long-term $0.9 \%$ growth could be achieved with a harvest rate of $11.3 \%$ and sustainable harvest of $12.1 \%$ $(\lambda=1$; Fig. 4A). When harvest was additive, increasing nonharvest mortality was required to offset equivalent decreases in hunting mortality to prevent changes in $\lambda$ (Fig. 4B). In addition, recruitment positively influenced harvest rate when other vital rates were fixed (Fig. 4B); a $20 \%$ increase in recruitment from 0.199 to 0.239 would result in a $24 \%$ increase in potential harvest rate.

We also used our model to investigate how differential harvest of population segments might affect composition of the midcontinent sandhill crane population. Given additive harvest of $6.6 \%$ (i.e., corresponding with $\lambda=1.009$ ) and estimates of hunting exposure from Krapu et al. (2011), potential harvest rates by breeding segment would be $4.7 \%$ for $\mathrm{WA}-\mathrm{S}, 6.3 \%$ for $\mathrm{NC}-\mathrm{N}, 8.3 \%$ for $\mathrm{WC}-\mathrm{A}$, and $9.9 \%$ for EC-M. By subspecies, differential harvest rates based on hunting exposure would be $5.2 \%$ for lesser and $8.9 \%$ for greater sandhill cranes. Under a scenario where recruitment and nonharvest mortality rates were equal among breeding segments or between subspecies and harvest was additive at differential rates, asymptotic population growth rates would be 1.028 for WA-S, 1.012 for NC-N, 0.992 for WC-A, 0.977 for EC-M, 1.023 for lesser sandhill cranes, and 0.986 for greater sandhill cranes. If these hypothetical long-term growth rates persisted, the entire population would increase 

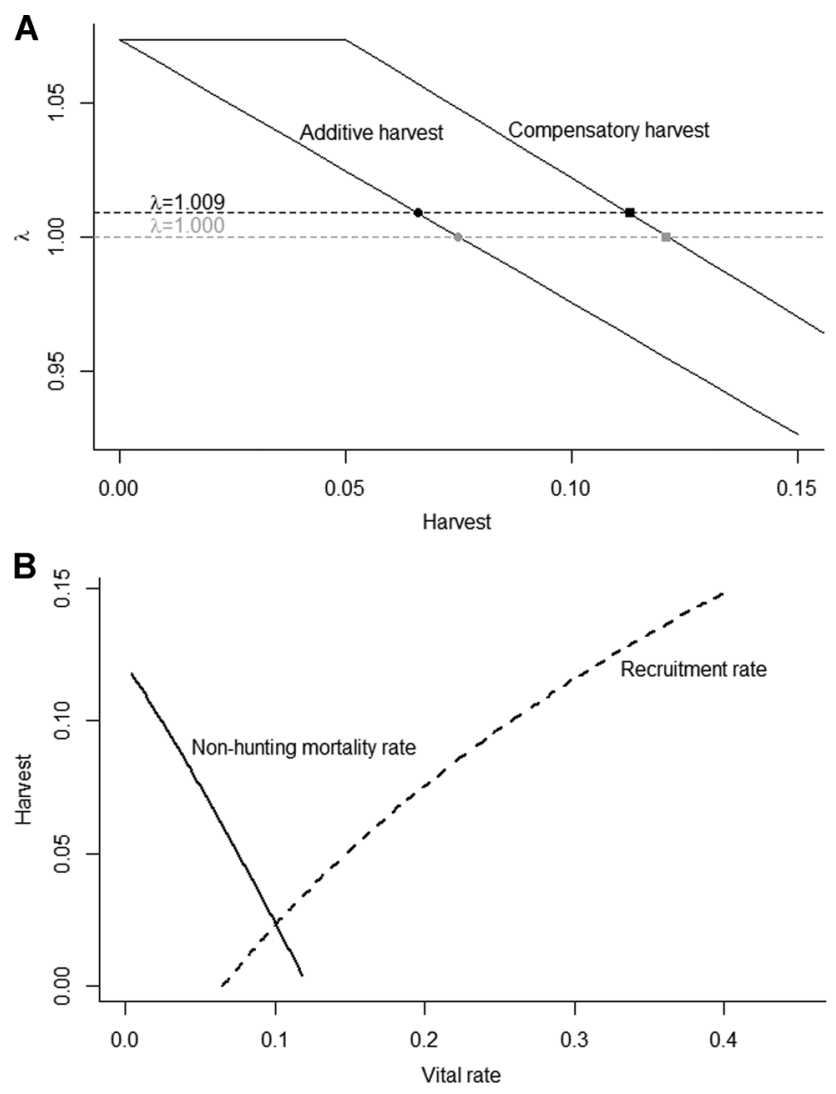

Figure 4. Relationship between potential harvest rate and predicted longterm finite growth rate $(\lambda)$ of sandhill cranes in the midcontinent population under assumptions of hunting mortality that is additive or compensatory to nonharvest mortality (A). Relationships between harvest rate that would sustain a $0.9 \%$ annual growth rate and nonharvest mortality (solid line) and recruitment (dashed line; B).

at $0.9 \%$ annually, but composition would change over time. During a hypothetical 20 -year period, the proportion of WA-S would increase from 0.42 to $0.57, \mathrm{NC}-\mathrm{N}$ would remain stable at 0.21 , WC-A would decrease from 0.21 to 0.15 , and EC-M would decrease from 0.14 to 0.07 . By subspecies, lesser sandhill cranes would increase from 0.63 to 0.78 and greater sandhill cranes would decrease from 0.37 to 0.22 .

\section{DISCUSSION}

Management decisions rarely are supported by complementary time-, age-, and site-specific estimates of survival, recruitment, and population trend. More often, as has been the case for sandhill cranes, managers informally generalize and synthesize studies of population processes from different time periods and geographic areas. Synthesis of information from varied sources in population projection models can promote understanding of demographic processes, improve the precision of estimates, reveal contradictions, and support exploration of management alternatives. Our results suggest demographics of sandhill cranes in the midcontinent population are similar to those of other long-lived species (Cooch et al. 2014). A prospective elasticity analysis suggested that population growth rate was most sensitive to changes in adult survival, a common result for species with similar life-history characteristics (Sxther and Bakke 2000). Although not available for this population, we suspect that annual variation in adult survival was characteristically low as compared to annual variation in recruitment and juvenile survival, which likely influences annual changes in population growth, a common result in retrospective analyses (Flint et al. 2006; Wilson et al. 2012, 2016).

Models need not be complex to be useful for certain purposes; rather, complexity should be commensurate with understanding. For example, we were unable to consider uncertainty in parameter estimation, covariation in vital rates, density dependence, and stochasticity because we did not have available data or adequate information on these natural processes. For sandhill cranes in the midcontinent population, the current state of knowledge supported a general description of life history comprising 4 age-classes and associated transitions, although more complex models have been used for this species in populations where parameters could be estimated with greater specificity (Gerber and Kendall 2016). We fixed survival of juveniles as a $10 \%$ reduction of adult survival because juvenile sandhill cranes and geese generally have been found to be more vulnerable to harvest than adults (Tacha et al. 1985, Menu et al. 2002). We also assumed that birds $\geq 3$ years of age were potential breeders (Nesbitt 1992, Gerber et al. 2014), although greater delays in reproduction have been suggested (Tacha and Vohs 1984, Gerber and Kendall 2016). Model results were relatively invariant to breeding potential of younger birds and changes in juvenile survival because only a small component of sandhill cranes comprise these individual age classes and recruitment would be lowest for young birds. Even with our simpler model and assumptions, estimates of survival, recruitment, and population trend were nonetheless congruent, strengthening confidence in methods and estimates. Use of models for evaluation of perturbations is robust relative to use of models for prediction because the baseline is constant, and alternatives differ only with respect to parameters that are manipulated. Specifically, we used the model to explore different harvest scenarios, and how changes in nonharvest mortality and recruitment could influence population dynamics and potential harvest rates under different population growth rates.

Estimated harvest that a population can sustain requires understanding of potential density-dependent changes in nonharvest mortality that may occur under varying harvest rates. Additive harvest has been found for large-bodied and long-lived bird species such as geese (Rextad 1992). Moreover, there is little evidence supporting mechanisms for density-dependent mortality, which is the most common mechanism for compensatory harvest mortality (Sedinger and Herzog 2012). Sandhill cranes in the midcontinent population distribute widely during most of the year (Krapu et al. 2011), which would restrict limited food resources as a mechanism for density-dependent mortality. Agricultural grains consumed by sandhill cranes during migration and winter, a primary food source during times when the birds are most concentrated (Reinecke and Krapu 1986), are also 
consumed by millions of other individuals from multiple species (e.g., migratory geese and ducks). Thus, a decrease in sandhill crane numbers from hunting may have little influence on food availability during migration or winter when considering overwhelming numbers of other species using the same resources. A potential exception may exist during spring migration at the Platte River in Nebraska when density of sandhill cranes peaks annually and competition for food is possible (Pearse et al. 2010). Nevertheless, few deaths have been reported during this time in the annual cycle (Krapu et al. 2014), although there is potential for density-dependent recruitment if limited food resources during spring influence later reproduction (Sedinger and Alisauskas 2014). Moreover, harvest rates resulting from hypothesized additive harvest provide population estimates derived from Lincoln estimation (Lincoln 1930, Alisauskas et al. 2011) that are more compatible with available estimates of harvest and abundance. Considering an estimated 39,000 harvested birds $(30,000$ retrieved birds; 4,000 unretrieved harvest [Dubovsky 2017]; 5,000 subsistence harvest [Naves and Keating 2019]), an additive harvest rate $(6.6 \%)$ would result in a point estimate of 591,000 sandhill cranes in the midcontinent population. In contrast, a compensatory harvest rate of $11.3 \%$ would result in a point estimate of only 345,000 individuals. Spring survey estimates and past research suggest $>500,000$ sandhill cranes exist in the midcontinent population (Kinzel et al. 2006, Dubovsky 2017), which better corresponds with estimates based on the additive harvest hypothesis.

Our model and supporting estimates suggest that sandhill cranes in the midcontinent population have been harvested at a rate of approximately $6.5 \%$ annually in recent times. Available information also suggests that the estimated number of sandhill cranes killed by hunters has increased at twice the rate of population growth over a 3-decade period for this population, a situation that was initially identified in the 2000s (Dubovsky and Araya 2008). Although not sustainable long term, increasing recruitment could account for continued harvest increases. If managers discover that harvest rates need to be altered to meet management goals, potential options include modifying daily bag limits, season lengths, or number of hunters participating (Araya and Dubovsky 2008, Dubovsky and Araya 2008). The correlation between active hunters and harvested birds suggests that reducing numbers of hunters would be a viable method to reduce harvest rate, especially if implemented in locations with greater abundance or higher harvest rates.

Biologists have managed sandhill cranes in the midcontinent population as a single collective (Central Flyway Webless Migratory Game Bird Technical Committee 2018), yet this management population has a more complex structure of 2 genetically distinct subspecies and 4 breeding segments with unique breeding areas, migratory pathways and chronology, and wintering sites (Krapu et al. 2011, 2014). If harvest rates differed among breeding segments and between subspecies as indicated by spatial analysis of fall and wintering locations (Krapu et al. 2011), then distinct groups of sandhill cranes could be increasing in numbers and others decreasing, while the entire group exhibits modest overall growth. Ignoring geographic variation in vital rates when developing population models can lead to biased growth projections (Rockwell et al. 2012, Coates et al. 2018). Differential harvest and vital rates have been reported in the midcontinent population of snow geese (Chen caerulescens) for which reduced survival rates of more southerly nesting individuals may have been caused by their earlier migration into hunted areas, which extended exposure to harvest (Alisauskas et al. 2011). Our model projections suggest that if differential harvest has occurred, composition could shift in favor of lesser sandhill cranes experiencing lower harvest rates and reduced numbers of greater sandhill cranes that may be experiencing unsustainable harvest. These results are speculative because we did not have supporting data to determine if harvest rates or long-term recruitment rates differed among groups. Groupspecific demographic and harvest rates have been identified as a research need (Collins et al. 2016), and our results support that this information is necessary to further explore how segments of a population can have divergent dynamics, while status of the overall group gives little indication of potential unsustainable harvest of assemblages within.

Monitoring population parameters are critical activities in supporting management of harvested species (Williams et al. 2002). Sandhill crane managers of the midcontinent population have identified improving the spring abundance survey as a research need (Case and Sanders 2009, Collins et al. 2016). We viewed annual estimates from the spring survey with skepticism and used results only to derive longterm growth rate. Identification of subtle shorter-term patterns would not be possible given the extreme annual variation in survey results, most of which is likely due to nuisance sources rather than annual changes in abundance (Krapu et al. 2014, Pearse et al. 2015). Even with survey improvements, monitoring segments of the midcontinent population of sandhill cranes would require different methods because subspecies and breeding segments cannot be separately monitored with the current spring survey. Initiation of a banding program could be one source of data to meet these needs and provide considerable additional information useful for management (Alisauskas et al. 2013, Arnold 2018). Reliable subspecies determination can be made using morphological measurements of live birds during banding (VonBank et al. 2019), allowing for estimation of subspecies-specific survival and harvest rates. Subspecies-specific harvest estimates would provide proportional harvest composition and facilitate estimates of abundance by subspecies if coupled with banding results (Lincoln 1930). Finally, recruitment estimates by subspecies could be determined by conducting age composition surveys in fall by taking advantage of generally distinct fall-staging areas by subspecies (Krapu et al. 2011). Estimated age ratios from these surveys are comparable with recruitment estimates derived from more-expensive telemetry methods. Combining subspecies-specific survival, harvest rate, and recruitment could be used in conjunction with our population model to determine the necessity of managing 
sandhill cranes in the midcontinent population with greater specificity.

\section{MANAGEMENT IMPLICATIONS}

Long-term survey estimates and model results suggest that harvest of sandhill cranes in the midcontinent population has been sustainable and may continue to be if recruitment rates do not decrease or nonharvest mortality rates do not increase substantially. Because of the life-history characteristics of the species, especially low recruitment, a continued conservative approach to harvest regulation would minimize risk of overharvest. Adult survival rate most influenced longterm population growth rate and harvest and natural mortality rates were similar in magnitude; therefore, modifying harvest rate is likely the most consequential action managers can take to influence population growth rate for these wideranging birds. Managing the midcontinent population of sandhill cranes as a single entity involves potential risks to certain population segments. Exploring risks and additional ramifications of this management practice would require estimating vital rates at a finer scale. Estimating population parameters by subspecies is potentially feasible and would allow for determining subspecies-specific population growth and harvest rates.

\section{ACKNOWLEDGMENTS}

Any use of trade, firm, or product names is for descriptive purposes only and does not imply endorsement by the United States Government. We thank numerous field assistants for their tireless support in collecting data. B. D. Gerber and D. H. Johnson provided comments to earlier versions of this manuscript. We thank the Region 6 of the United States Fish and Wildlife Service and United States Geological Survey, Platte River Priority Ecosystems Study, Central Flyway Council, and the Webless Migratory Game Bird Research Fund for funding and in-kind assistance.

\section{LITERATURE CITED}

Alisauskas, R. T., T. W. Arnold, J. O. Leafloor, D. L. Otis, and J. S. Sedinger. 2013. Lincoln estimates of mallard (Anas platyrhynchos) abundance in North America. Ecology and Evolution 4:132-143.

Alisauskas, R. T., R. F. Rockwell, K. W. Dufour, E. G. Cooch, G. Zimmerman, K. L. Drake, J. O. Leafloor, T. J. Moser, and E. T. Reed. 2011. Harvest, survival, and abundance of midcontinent lesser snow geese relative to population reduction efforts. Wildlife Monographs 179:1-42.

Araya, A. C., and J. A. Dubovsky. 2008. Temporal distribution of harvested mid-continent sandhill cranes within the Central Flyway states during the 1997-2001 hunting seasons. Proceedings of the North American Crane Workshop 10:50-57.

Arnold, T. W. 2018. Using ring-recovery and within-season recapture data to estimate fecundity and population growth. Ecology and Evolution 8:10298-10305

Arnold, T. W., C. N. D. Sobrino, and H. M. Specht. 2016. Annual survival rates of migratory shore and upland game birds. Wildlife Society Bulletin 40:470-476.

Buller, R. J. 1967. Sandhill crane study in the Central Flyway. U.S. Department of the Interior, Fish and Wildlife Service Special Report Wildlife No. 113, Washington, D.C., USA.

Buller, R. J. 1979. Lesser and Canadian sandhill crane populations, age structure, and harvest. U.S. Department of the Interior, Fish and Wildlife Service Special Report Wildlife No. 221, Washington, D.C., USA.
Canadian Wildlife Service. 2017. National harvest survey. https://www. canada.ca/en/environment-climate-change/services/bird-surveys/waterfowl/ national-harvest.html. Accessed 1 May 2019.

Case, D., and S. J. Sanders. 2009. Priority information needs for sandhill cranes: a funding strategy. U.S. Fish and Wildlife Service Publications. https://www.fws.gov/migratorybirds/pdf/surveys-and-data/Info-NeedsSandhill-Crane-II_2016.pdf. Accessed 1 May 2019.

Caswell, H. 2001. Matrix population models. Second edition. Sinauer Associates, Sunderland, Massachusetts, USA.

Central Flyway Webless Migratory Game Bird Technical Committee, compiler. 2018. Management guidelines for the mid-continent population of sandhill cranes. U.S. Fish and Wildlife Service Migratory Bird Management Office, Golden, Colorado, USA.

Coates, P. S., B. G. Prochazka, M. A. Ricca, B. J. Halstead, M. L. Casazza, E. J. Blomberg, B. E. Brussee, L. Wiechman, J. Tebbenkamp, S. C. Gardner, et al. 2018. The relative importance of intrinsic and extrinsic drivers to population growth vary among local populations of greater sage-grouse: an integrated population modeling approach. Auk 135:240-261.

Collins, D., T. Cooper, J. Dubovsky, and D. Fronczak. 2016. Priority information needs for sandhill cranes II-a funding strategy. U.S. Fish and Wildlife Service Publications. https://www.fws.gov/migratorybirds/ pdf/surveys-and-data/Info-Needs-Sandhill-Crane-II_2016.pdf. Accessed 1 May 2019.

Cooch, E. G., M. Guillemain, G. S. Boomer, J.-D. Lebreton, and J. D. Nichols. 2014. The effects of harvest on waterfowl populations. Wildfowl Special Issue 4:220-276.

Deines, A., E. Peterson, D. Boeckner, J. Boyle, A. Keighley, J. Kogut, J. Lubben, R. Rebarber, R. Ryan, B. Tenhumberg, et al. 2007. Robust population management under uncertainty for structured population models. Ecological Applications 17:2175-2183.

Drewien, R. C., W. M. Brown, and W. L. Kendall. 1995. Recruitment in Rocky Mountain greater sandhill cranes and comparison with other crane populations. Journal of Wildlife Management 59:339-356.

Dubovsky, J. A. 2017. Status and harvests of sandhill cranes: Midcontinent, Rocky Mountain, lower Colorado River Valley and eastern populations. Administrative Report, U.S. Fish and Wildlife Service, Lakewood, Colorado, USA.

Dubovsky, J. A., and A. C. Araya. 2008. Hunting success for midcontinent sandhill cranes in the Central Flyway: comparing current and historic results. Proceedings of the North American Crane Workshop 10:58-64.

Eberhardt, L. L. 2002. A paradigm for population analysis for long-lived vertebrates. Ecology 83:2841-2854.

Fair, J., E. Paul, and J. Jones. 2010. Guidelines to the use of wild birds in research. Ornithological Council, Washington, D.C., USA.

Flint, P. L., J. B. Grand, T. F. Fondell, and J. A. Morse. 2006. Population dynamics of greater scaup breeding on the Yukon-Kuskokwim Delta, Alaska. Wildlife Monographs 162:1-22.

Fronczak, D. L., D. E. Andersen, E. E. Hanna, and T. R. Cooper. 2015. Annual survival rate estimate of satellite transmitter-marked eastern population greater sandhill cranes. Journal of Fish and Wildlife Management 6:464-471.

Gerber, B. D., J. F. Dwyer, S. A. Nesbitt, R. C. Drewien, C. D. Littlefield, T. C. Tacha, and P. A. Vohs. 2014. Sandhill crane (Antigone canadensis), version 2.0. The Birds of North America Online. https://birdsna.org/ Species-Account/bna/species/sancra. Accessed 1 May 2019.

Gerber, B. D., and W. L. Kendall. 2016. Considering transient population dynamics in the conservation of slow life-history species: an application to the sandhill crane. Biological Conservation 200:228-239.

Harris, J., and C. Mirande. 2013. A global overview of cranes: status, threats and conservation priorities. Chinese Birds 4:189-209.

Johnson, D. H. 1979. Modeling sandhill crane population dynamics. U.S. Department of the Interior, Fish and Wildlife Service Special Report Wildlife No. 222, Washington, D.C., USA.

Jones, K. L., G. L. Krapu, D. A. Brandt, and M. V. Ashley. 2005. Population genetic structure in migratory sandhill cranes and the role of Pleistocene glaciations. Molecular Ecology 14:2645-2657.

Kinzel, P. J., J. M. Nelson, R. S. Parker, and L. R. Davis. 2006. Spring census of mid-continent sandhill cranes using aerial infrared videography. Journal of Wildlife Management 70:70-77.

Krapu, G. L., D. A. Brandt, K. L. Jones, and D. H. Johnson. 2011. Geographic distribution of the mid-continent population of sandhill 
cranes and related management applications. Wildlife Monographs 175:1-38.

Krapu, G. L., D. A. Brandt, P. J. Kinzel, and A. T. Pearse. 2014. Spring migration ecology in the mid-continent population of sandhill cranes with an emphasis on the central Platte River Valley, Nebraska. Wildlife Monographs 189:1-44.

Lewis, J. C. 1979. Field identification of juvenile sandhill cranes. Journal of Wildlife Management 43:211-214.

Lincoln, F. C. 1930. Calculating waterfowl abundance on the basis of band returns. Circular 118, U.S. Department of Agriculture, Washington, D.C., USA.

Lingle, G. R. 1992. History and economic impact of crane-watching in central Nebraska. Proceedings of the North American Crane Workshop 6:33-37.

Longmire, J. L., R. E. Ambrose, N. C. Brown, T. J. Cade, T. Maechtle, W. S. Seegar, F. P. Ward, and C. M. White. 1991. Use of sex-linked mini-satellite fragments to investigate genetic differentiation and migration of North American populations of the peregrine falcon (Falco peregrinus). Pages 217-229 in T. Burke, F. G. Dolf, A. Jefferys, and R. Wolff, editors. DNA fingerprinting: approaches and applications. Birkhauser Press, Basil, Switzerland.

Menu, S., G. Gauthier, and A. Reed. 2002. Changes in survival rates and population dynamics of greater snow geese over a 30-year period: implications for hunting regulations. Journal of Applied Ecology 39:91-102.

Miller, R. S., and J. P. Hatfield. 1974. Age ratios of sandhill cranes. Journal of Wildlife Management 38:234-242.

Naves, L. C., and J. M. Keating. 2019. Alaska subsistence harvest of birds and eggs, 2004-2017 data book. Report 2019-04. Alaska Migratory bird Co-management Council, Anchorage, Alaska, USA.

Nesbitt, S. A. 1992. First reproductive success and individual productivity in sandhill cranes. Journal of Wildlife Management 56:573-577.

Pearse, A. T., D. A. Brandt, and G. L. Krapu. 2020. Fecundity data for midcontinent sandhill cranes, 2003-2006. U.S. Geological Survey data release. https://doi.org/10.5066/P9WMRBMV. Accessed 1 Feb 2020.

Pearse, A. T., G. L. Krapu, D. A. Brandt, and P. J. Kinzel. 2010. Changes in agriculture and abundance of snow geese affect carrying capacity of sandhill cranes in Nebraska. Journal of Wildlife Management 74: 479-488.

Pearse, A. T., G. L. Krapu, D. A. Brandt, and G. A. Sargeant. 2015. Timing of spring surveys for midcontinent sandhill cranes. Wildlife Society Bulletin 39:87-93.

Post van der Burg, M., and A. J. Tyre. 2011. Integrating info-gap decision theory with robust population management: a case study using the mountain plover. Ecological Applications 21:303-312.

R Core Team. 2019. R: a language and environment for statistical computing. R Foundation for Statistical Computing, Vienna, Austria.

Reinecke, K. J., and G. L. Krapu. 1986. Feeding ecology of sandhill cranes during spring migration in Nebraska. Journal of Wildlife Management 50:71-79.
Rextad, E. A. 1992. Effect of hunting on annual survival of Canada geese in Utah. Journal of Wildlife Management 53:1088-1103.

Rhymer, J. M., M. G. Fain, J. E. Austin, D. H. Johnson, and C. Krajewski. 2001. Mitochondrial phylogeography, subspecific taxonomy, and conservation genetics of sandhill cranes (Grus canadensis; Aves: Gruidae). Conservation Genetics 2:203-218.

Rockwell, R. F., K. W. Dunfour, E. T. Reed, and D. N. Koons. 2012. Modeling the midcontinent population of lesser snow geese. Pages 178-201 in J. O. Leafloor, T. J. Moser, and B. D. J. Batt, editors. Evaluation of special management measures for midcontinent lesser snow geese and Ross's geese. U.S. Fish and Wildlife Service, Washington, D.C., USA, and Canadian Wildlife Service, Ottawa, Ontario, Canada.

Sæther, B.-E., and Ø. Bakke. 2000. Avian life history variation and contribution of demographic traits to the population growth rate. Ecology 81:642-653.

Sedinger, J. S., and R. T. Alisauskas. 2014. Cross-seasonal effects and the dynamics of waterfowl populations. Wildfowl (Special Issue) 4:277-304.

Sedinger, J. S., and M. P. Herzog. 2012. Harvest and dynamics of duck populations. Journal of Wildlife Management 76:1108-1116.

Sharp, D. E., and W. O. Vogel. 1992. Population status, hunting regulations, hunting activity, and harvests of mid-continent sandhill cranes. Proceedings of the North American Crane Workshop 6:24-32.

Tacha, T. C., C. Jorgenson, and P. S. Taylor. 1985. Harvest, migration, and condition of sandhill cranes in Saskatchewan. Journal of Wildlife Management 49:476-480.

Tacha, T. C., and P. A. Vohs. 1984. Some population parameters of sandhill cranes from mid-continental North America. Journal of Wildlife Management 48:89-98.

VonBank, J. A., D. A. Brandt, A. T. Pearse, D. B. Wester, and B. M. Ballard. 2019. Using morphological measurements to predict subspecies of midcontinent sandhill cranes. Wildlife Society Bulletin 43:737-744.

Wheeler, R. H., and J. C. Lewis. 1972. Trapping techniques for sandhill crane studies in the Platte River Valley. U.S. Department of the Interior, U.S. Fish and Wildlife Service Resource Publication 107, Washington, D.C., USA.

Williams, B. K., J. D. Nichols, and M. J. Conroy. 2002. Analysis and management of animal populations-modeling, estimation, and decision making. Academic Press, San Diego, California, USA.

Wilson, H. M., P. L. Flint, A. N. Powell, J. B. Grand, and C. L. Moran. 2012. Population ecology of breeding Pacific common eiders on the Yukon-Kuskokwim Delta, Alaska. Wildlife Monographs 182:1-28.

Wilson, S., K. C. Gil-Weir, R. G. Clark, G. J. Robertson, and M. T. Bidwell. 2016. Integrated population modeling to assess demographic variation and contributions to population growth for endangered whooping cranes. Biological Conservation 197:1-7.

Associate Editor: Anthony Roberts. 